\title{
A FOLKLORIST IN THE SOVIET SPOTLIGHT
}

\author{
RITA TREIJA \\ Senior Researcher \\ Institute of Literature, Folklore and Arts \\ University of Latvia \\ Mūkusalas iela 3, Riga, LV-1423, Latvia \\ e-mail: rita.treija@lulfmi.lv
}

\begin{abstract}
The article seeks to illuminate the ideologically motivated circumstances of Latvian folklore studies during the period of unconditional Soviet totalitarianism. With the strengthening of the Soviet occupation regime in Latvia in the late 1940s, many interwar folklorists became victims of ideologically motivated disdain and subsequent career limitation. 'Bourgeois' scholarship and the methods applied in folklore studies during the interwar period were denounced and recognised as harmful to the new Soviet order. The central part of the article presents a case study of one individual folklorist of the time, Anna Bērzkalne (1891-1956). Both increasing criticism of Bērzkalne's folklore research approach (the historical-geographical method) and her efforts to accommodate the requirements of the Soviet regime have been analysed.
\end{abstract}

KEYWORDS: history of folkloristics • sovietisation • historical-geographical method • Anna Bērzkalne • Latvia

\section{N T RODUCTION}

The Soviet period in Latvian folkloristics followed the dynamic and disciplinary foundation-laying interwar period, in which folkloristics in Latvia developed as an academic discipline, flourished, and received its institutional background - at the Archives of Latvian Folklore and the Faculty of Philosophy and Philology of the University of Latvia. The relevant contexts of folklore research of that time, such as international cooperation, national cultural policies, the process of institutionalisation, and the integration of the discipline into higher education have been thoroughly studied in collective monographs edited by Dace Bula $(2014 ; 2017)$. The interwar period presents several research paradigms, the dominant being the historical-geographical school; the literary

* This article was supported by the Latvian Council of Science via the Latvian Folkloristics (1945-1985) research project (No. lzp-2018/2-0268). 
approach to folklore texts; and the use of folklore for historic and ethnographic explorations (Bula 2017: 14).

During the interwar period folklore studies also had a rather high reputation and was among the nationally important disciplines. The Archives of Latvian Folklore (founded in 1924) was one of the first research institutes of the new independent state (established in 1918). Several folklore scholars, Jēkabs Lautenbahs, Kārlis Straubergs and Pēteris Šmits, were among the first professors at the University of Latvia (founded 1919), and the outstanding folk song collector and publisher Krišjānis Barons became one of the first honorary members of the University. (Bula 2017: 21) Although the discipline of folklore studies in Latvia encountered difficulties, such as the financial shortcomings of the Archives of Latvian Folklore and a lack of doctoral level education in Riga, the usefulness of folklore studies was not questioned. In fact, it was exactly the opposite, for a large part of society, among them many schoolchildren, were involved in collecting folklore, which they considered a matter of national pride.

For the folklorists of the interwar period, the changes in individual working lives after the Second World War were comprehensive. Those who stayed in occupied Latvia faced the Soviet regime on a very personal level. Therefore, a researcher working on the disciplinary history of folkloristics can ask: what tactics were used to survive the harshest years of Soviet Academia? And how did Latvian folklorists cope with the ideology of unconditional Soviet totalitarianism?

\section{THE BIG DIVIDE}

For the disciplinary history, the end of the Second World War and the beginning of the half-century Soviet occupation meant a loss of the Latvian perspective. The Nazi occupation (1941-1945), however harmful to Latvian political independence, did not introduce a new intellectual direction; a new era in Latvian folkloristics only began after the establishment of the Soviet regime in 1945 (Bula 2017: 14). This meant an abrupt end to the work Latvian folklorists had started.

The big shift in 1945 divided the former Latvian intelligentsia, among them folklore researchers, into two geographically and intellectually separate scholarly communities. Many Latvians who were educated professionals in the field of folklore studies were exiled. "Those who fled - Kārlis Straubergs, Ludis Bērziṇš, and Arveds Švābe - sought to continue their scholarly careers in exile, despite being disconnected from their academic milieus and source materials" (Bula 2017: 14). Osvalds Lìdeks and Eduards Zicāns did not continue the academic path in exile. Fruitful initiatives in the field of Latvian traditional culture and mythology studies were also carried out by Latvian scholars from other fields of humanities, for instance by linguist Edìte HauzenbergaŠturma and by theologian Haralds Biezais.

Using approaches learned in Latvia, the exiled intellectuals continued teaching others (the starting point being the displaced persons' camps in post-war Germany and the joint higher education institution for Latvian, Lithuanian and Estonian refugees, Baltic University). In addition, they educated themselves to be open to the folklore practices of the countries they relocated to. They formed the networks of cooperation and continued researching Latvian folklore in their new homelands, including Sweden, Germany, 
the United States of America, and Canada. Communication between the exiled folklorists and those in Soviet Latvia was limited, especially during the initial period of the occupation. Scholars became the caretakers of the traditional Latvian culture abroad.

In addition to Latvians, some of the most visible folklorists of other Baltic countries were forced to go to exile. Thus, Oskar Loorits, the founder of the Estonian Folklore Archive in Tartu (1927), fled from the Soviet occupation to Sweden. The Lithuanian folklorist Jonas Balys, in his turn, left after establishing and chairing the Lithuanian Folklore Archives in Kaunas (1935), continuing his career in the United States of America. He was the researcher and head librarian for the Slavic and Central European Division of the Library of Congress in Washington, DC. The questions of Baltic folklorists in exile have been examined in several research articles (Gale Carpenter 1988; 2017; Klein 2017), although still there are many areas that need further in-depth historical study.

Folklorists who stayed in Latvia after the Second World War - Anna Bērzkalne (1891-1956), Pēteris Birkerts (1881-1956), Jānis Alberts Jansons (1892-1971), and Emilis Melngailis (1874-1954) - had to find "a middle ground between their past scholarly endeavours and the realities of the Soviet present" (Bula 2017: 14). This included both revising the way they presented their scientific work, research methods, and scholarly principles as well as the approach to the presentation of teaching materials at the University when it came to the lectures and seminars on Latvian folklore. The new Soviet ideas had to be taken into consideration, since there was a clear divide between the unwanted past and the tendentiously imprinted Soviet present. In the late 1940s, the professional lives of many interwar period folklorists were exposed to ideologically motivated ostracising. The harsh and cruel public criticism of inter-war period scholars was supposed to be a step towards integration into united Soviet scholarship. These repressive acts contained an evaluation of a person's biography, previous publications, and the ideological position presented at lectures. Informing against colleagues was even a common practice. Thus, quite soon, the collegiate relationships of earlier times were replaced with suspicion. (Keruss 2011: 102-106)

\section{THE SOVIETISATION OF LATVIAN FOLKLORISTICS}

The cradle of the sovietisation of science was the Russian Soviet Republic where it took place as early as the first decades after the 1917 October Revolution (Sorokina 2011: 225). So-called Soviet folklore, traditional and quasi-traditional oral cultural forms with Soviet heroes, heroic events, etc., became a matter of interest and public collection in the 1920s (Panchenko 2005: 19). In Latvia, however, these phenomena emerged only in the late 1940s with the growing force of the second Soviet occupation.

The most extensive critical research into the Stalinist period in Latvian folkloristics, which includes the initiatives designed to produce new Soviet folklore between 1947 and 1954, has been carried out by Toms Kencis $(2017 ; 2019)$. His approach was to view this vivid page in the disciplinary history of Latvian folkloristics within the broader context of the Soviet totalitarian culture scheme:

Soviet Latvian folkloristics provides an excellent case study of reflexive linkage between knowledge production and power. As such it contributes to multiple 
fields, including but not limited to institutional histories, disciplinary history, and cultural studies under totalitarian regimes or Stalinism in particular. Additional dimensions of mapping disciplinary history in the Latvian Soviet Socialist Republic $[. .$.$] are relationships between the centre and peripheries, reinterpretation of the$ disciplinary heritage, and obvious impacts of individual actors on methodological questions and disciplinary agendas. In this regard, folkloristics is an especially interesting field of study due to the special historical role of folklore for state ideologies and its semi-public nature of a dual authorship agency combined of scholarly and personal sides. Within the official discourse on folklore, Soviet cultural research and cultural production was merged into a single process. At the end of the day, folkloristics in Soviet times was not just a discipline of scholarship. It was an integral part of a much larger project with an aim to create a whole new world. (Ķencis 2017: 154-155)

Indeed, during the years before Joseph Stalin's death in 1953, the development of folklore studies in the Latvian SSR was customised to the propagated vision of this 'whole new world' and the novel Soviet ideological system. In order to implement ideological work, a careful assessment of public opinion was carried out along with the application of several propaganda techniques, such as determining the contents of printed media, organising compulsory propaganda lectures in workplaces and extensive public meetings, publishing political literature, and eliminating most Latvian books printed before 1940 from public libraries (Šneidere 2003: 103-106). Of all the Soviet propaganda news sheets, the daily newspaper Cina ('Fight'), with 170,000 copies printed and distributed widely in the Republic, was the most influential. It was published jointly by the Central Committee of the Communist Party of Latvia, the Supreme Council of the Latvian SSR, and the Latvian SSR Council of People's Commissars. (Ibid.: 104) A critical publication about a particular individual in Cina was an obvious sign of the seriousness of the situation.

The Stalinist period is known for its harsh and comprehensive methods of repression. Two periods of mass deportation to Siberia, in 1941 and 1949, frequent arrests and convictions, denunciations and individual deportations made up the sinister psychological background of people's everyday lives in Stalinism. Occasionally, the repression policy in the first post-war years focused on particular problems, for example, the fight against cosmopolitanism and the individuals celebrating Western cultural values (Bleiere 2006: 115).

Dramatic changes in folkloristics took place during Soviet rule in Latvia. The Latvian exile historian Rolfs Ekmanis in the Latvian American magazine, Jaunā Gaita ('New Course') highlighted the comic effect of the Bolshevism in practice: dealing with ideological mistakes and shortcomings in Latvian folkloristics, distorting and interpreting the folk treasures according to the 'scientific' method of Marxist-Leninist-Stalinist ideology and, lastly, the creation of a new Soviet mythology (Ekmanis 1959: 116).

Unlike the comical manifestations of Soviet folklore, Soviet scholarship implied the subjection of personality to ideological needs, up to the tragedy of the individual's destiny. Latvian folklorists had to follow the research directions outlined in Moscow, no matter how absurd they were. Class struggle and slavophilism were identified as priority research topics in folklore studies. Regarding the use of folklore for political propaganda, some scholars have drawn parallels between the Nazi and Soviet regimes: 
The Marxist-Leninist school of ideology was first articulated by R. Pelše, ${ }^{1}$ who established its practical foundations in Latvia. As Pelše wrote, "Marxist Enlightenment" was to banish "bourgeois objectivity" and folklore would serve "as the spring for the history of ideology". In this respect there are similarities with the conscious employment of folklore for propaganda purposes by the Nazis. The specific policy concerning folklore (and related fields) was two-pronged: (1) folklore was to be analyzed for the expression of class struggle, and (2) it was to serve as a means for proving the existence of cultural ties between the Latvians and the Russians. In other words, folklore was an aid to Russification and proof that Latvians belonged in Russia not only politically but also culturally. It is therefore not surprising that folkloristic activities had an early and apparently vigorous start in Soviet Latvia. (Bunkše 1979: 209)

In 1945, the former centre of folklore studies in Latvia, the Archives of Latvian Folklore, became affiliated with the Latvian State University and renamed the Institute of Folklore. In 1946, it was incorporated into the Latvian SSR Academy of Sciences. Its name was changed to the Institute of Ethnography and Folklore in 1950, and later, as a result of structural reforms of 1956, to the Folklore Department. ${ }^{2}$ During the first Soviet years, the research staff of the Institute varied around ten people. This institution, as well as the University's Faculty of Philology, became helpful executives of the Soviet ideological order in Latvian humanities. This was possible thanks to the enthusiasm of a few individuals who accepted the promising offer of building their careers under these new ideological circumstances.

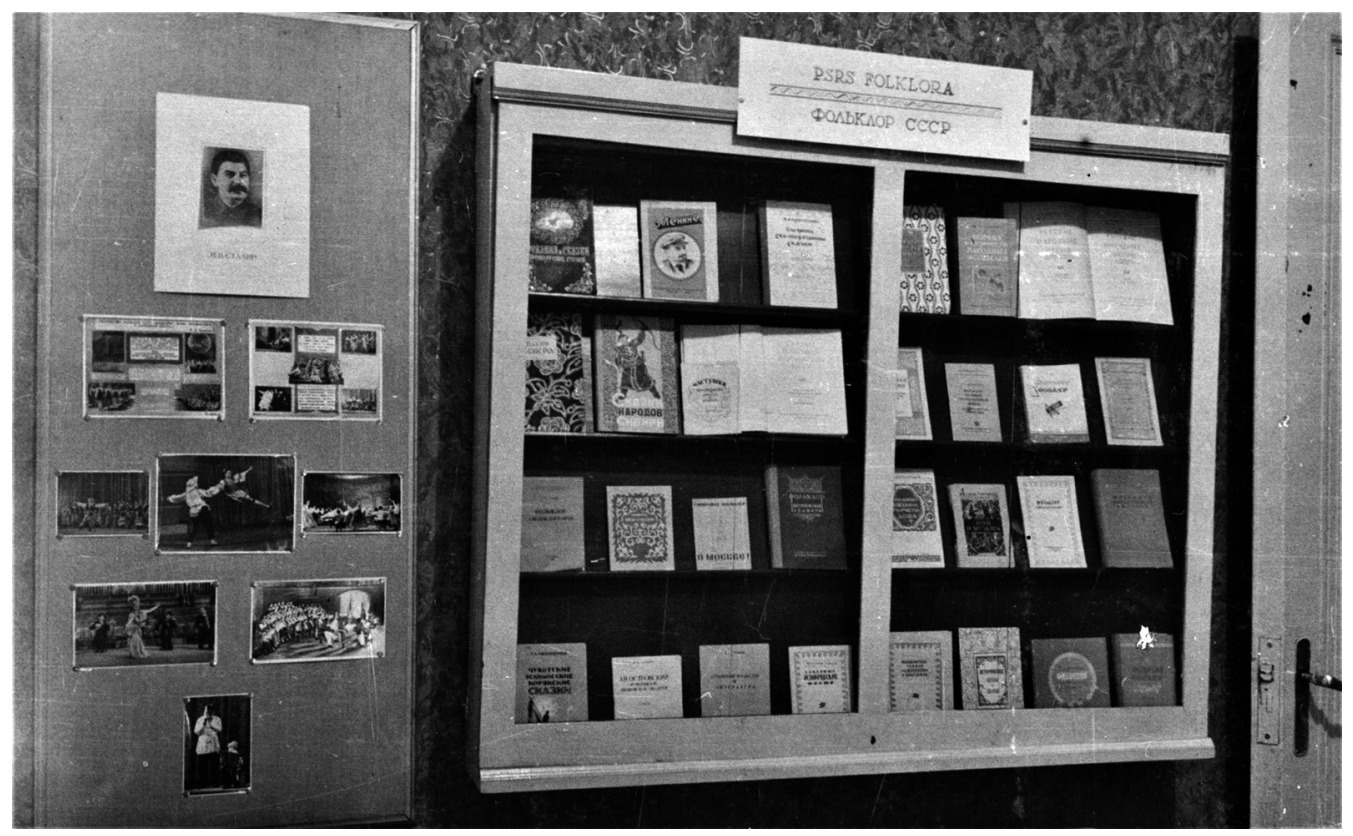

Photo 1. Exhibition of Soviet-era folklore at the Fundamental Library of the Academy of Sciences of the Latvian SSR during the 1st Conference of Baltic Folklorists in Riga. 1951. LFK f19510012. 
Jānis Niedre (1909-1987) was one of the most avid career-makers in the new setting of Soviet scholarship. Niedre had done some literary writing and ethnographic studies before; however, he had no academic education. Niedre was involved in various socialist movement activities in late 1920s and became a member of the Communist Party as early as 1934. Being the Deputy Director of the Institute of Folklore of the Academy of Sciences of the Latvian SSR, he denounced 'bourgeois' scholarship and the methods applied in the folklore studies of the interwar period. The main method to be discredited was the so-called Finnish School, also known as the historical-geographical method, founded by Finnish folklorists Julius and Kaarle Krohn. At the Department of Folklore, Faculty of Philology, Soviet negations grew like an avalanche. Being the main propagator of Soviet folklore and its studies in the Latvian SSR, Niedre showed vigilance in identifying the slightest non-compliance with the Soviet regime. His reference sources were the corresponding Marxist-Leninist articles, the decrees and orders of the ruling Communist Party, and, with respect to the theory of Soviet folkloristics, Yuriy Sokolov's book Russian Folklore (1938).

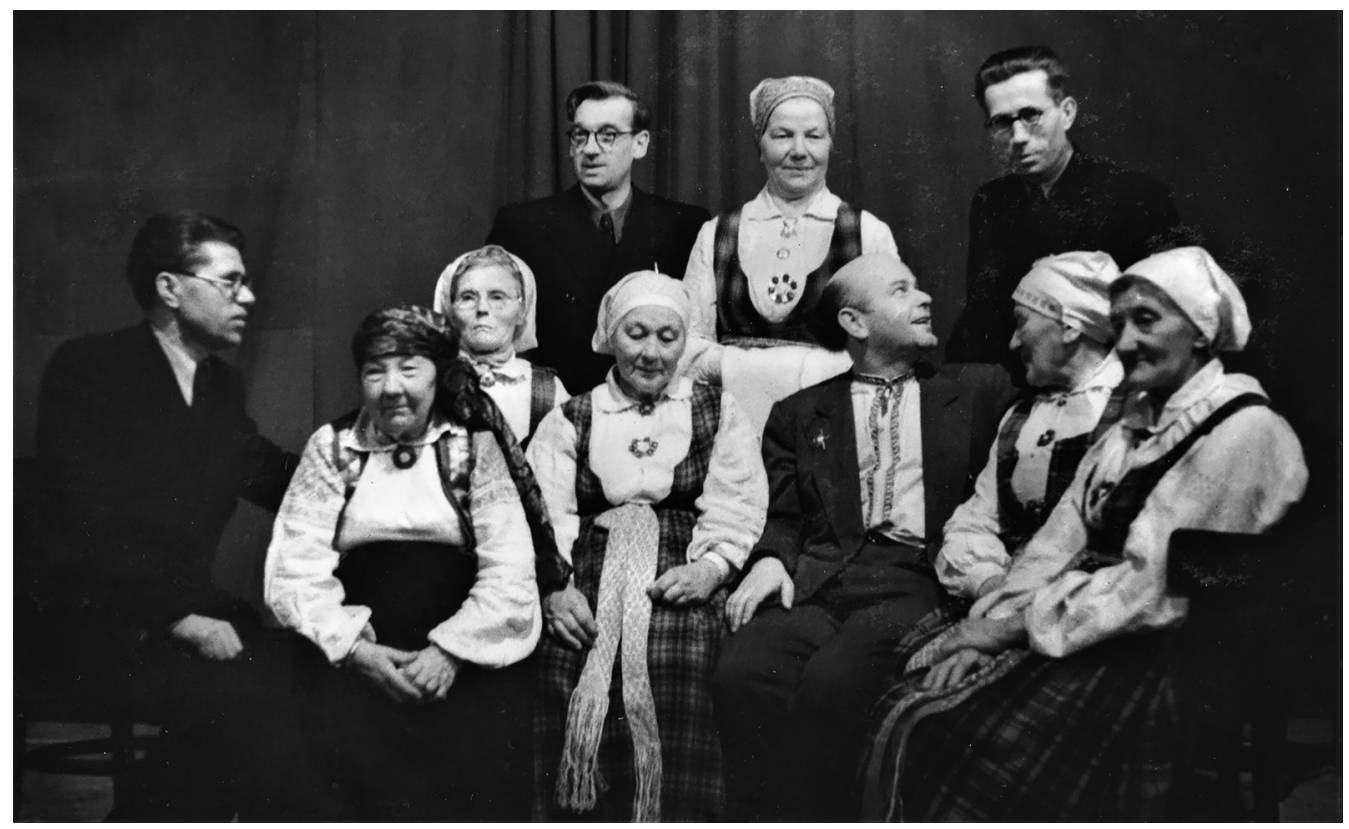

Photo 2. Folk singers and Soviet folklore researchers posing together during the 1st Conference of Baltic Folklorists in Riga. From the left: Prof. Viktor Sidelnikov (Moscow), Lìba Henzele, Elza Šulce, Prof. Vladimir Chicherov (Moscow), Emìlija Ezergaile, Cand. Andriy Kinko (Kiev), Deputy Director of the Institute of Folklore of the Academy of Sciences of the Latvian SSR, Cand. Jānis Niedre, Line Etmane, Emìlija Celmina. 1951. LFK f19510023.

From 1945 to 1956, scholars occupying the Latvian State University as well as the scientific institutions outside the University, took the process of sovietisation personally. The academic staff was given a chance to adapt to the requirements of the new regime by 'converting' themselves, thus demonstrating loyalty to the new power and its ideology. 
'Bourgeois' academia had to repent their sins in order to maintain their positions. Special evenings of self-criticism, or ideological confessions, were organised at the faculties of the University and at other education and cultural institutions. They followed a typical scenario: closed or open consultations in the institutions; revelation and comments on them in the press; denunciation of the problems and the personalities; 'confession' and 'repentance' of the guilty party; publication of colleagues' opinions or those of 'working class' in general (Klotinš 2018: 297). The aim of these campaigns was the ideological purification of the academic staff. These activities were similar to the totalitarian Soviet regime's reformative deeds against the Russian folklorists Sokolov and Vladimir Propp in the 1930s and 1940s (Kalnina 2007: 33). Additional correctional techniques were evening courses at the Marxism-Leninism University (mainly study of Vladimir Ilyich Lenin's and Stalin's written works). According to Jānis Stradiňš' study, the first relatively free period of the Soviet occupation ended in the summer of 1946 with the famous speech by Andrei Zhdanov proclaiming Soviet cultural doctrine in Moscow. From that time onwards the academic individual's compliance with communist doctrines and communist practice was achieved, through public humiliation. (Stradiňš 2004: 153-154)

Likewise, with the establishment of the Soviet order, the discipline of folklore studies and the folklore archives in Estonia (in Tartu) and Lithuania (established in Kaunas, later in Vilnius) were hit by ideological and structural alteration on an institutional level (Vidutis 1987; Korb 2017: 111-112; Kulasalu 2017; Goršič 2018: 122-123, 126-129; Saarlo 2018: 92). This included changes in folklore collecting and archiving strategies and circumspect choices of research topics. The large-scale collective fieldwork expeditions (so-called folklore expeditions), implemented by professional employees of the archives, became the main approach for recording oral traditional culture. Both the publication of folklore texts and their study had to be justified according to Soviet ideology. Prior to Stalin's death, such research themes as class struggle, songs of the working class, images of Lenin or Stalin in folklore, the Great Patriotic War, etc., were addressed. After 1953, these grotesque ideology-based approaches in folklore studies, as well as the creation of Soviet folklore, disappeared rapidly, not only in the three Baltic states but also in Soviet Russia, where they originated (Miller 1980: 65).

In all three Baltic countries, the scholars of the interwar past, especially those who had escaped their homelands, were turned into unacceptable and concealed historical figures. Their books were made inaccessible for young folklore students, and their research publications were quoted increasingly rarely, if ever. In the case of Estonia, previous folklore collections faced a process of censorship that included eliminating unwanted names, such as Loorits, from the records:

Loorits was one of the numerous people whose name was erased from the folklore manuscripts and indexes. All of the existing collections were censored [...] in the years 1945-1952, and the manuscript volumes were checked page by page. The methods of censorship included cut-outs, black ink, glue and leaving pages out from the volumes. Most of this work was carried out by folklorists themselves and censoring - named as controlling, checking or cleaning-was part of the working plans of the staff of the Folklore Department. Some volumes were controlled by people from the Central State Archives and there, censorship had been stricter. (Kulasalu 2017: 139) 
After the Second World War, not only in the Union of Soviet Socialist Republics, but also in other countries where government was based on communist ideology, such as the Socialist Republic of Romania, a wide range of scientific fields and numerous scholars had to cope with the burden of the new ideological principles and repressions. There was no critical discussion on the applicability of Marxism to science, as Marxism, in the words of historian Iurie Stamati (2015: 85), in reality was a dogma.

\section{CASE STUDY: ANNA BĒRZKALNE}

In order to have a detailed understanding of the disciplinary history of Latvian folklore studies in the early Soviet period, the case of one folklorist, Bērzkalne, is worth illuminating. The historical investigation presented here is the result of wide study of primary sources (Treija 2017; 2018), and so can be viewed as a microhistory of the history of folklore studies. Thus, tracing the dynamics of the time and constructing knowledge production in the field of folkloristics, privileges of biography as a small scale history are kept in mind: "[...] writing history at the micro scale of a single scientist makes it possible to encompass all the social, political, intellectual, cultural and religious factors which interact" (Kaeser 2008: 9).

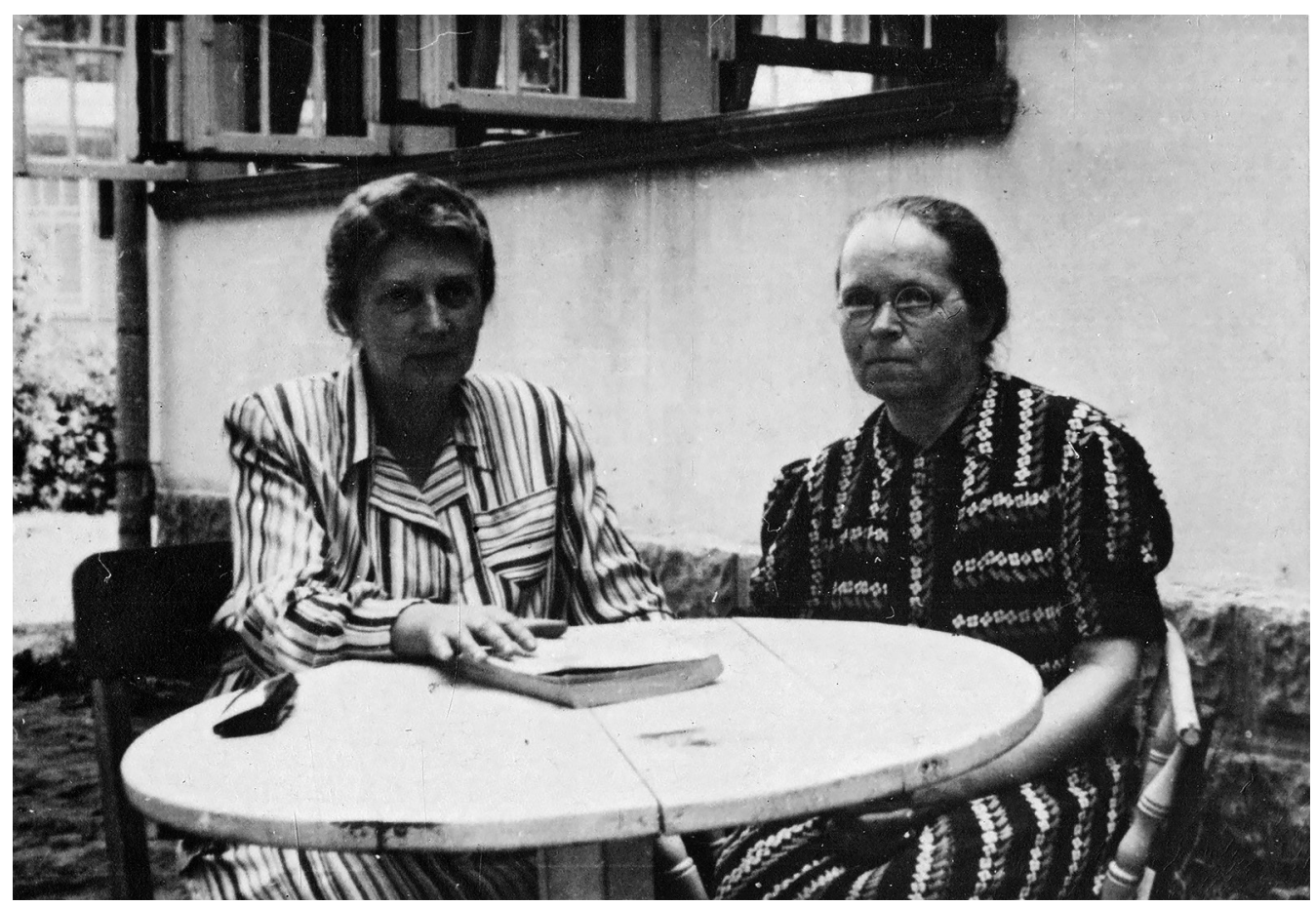

Photo 3. Latvian folklorist Anna Bèrzkalne (right) with Russian Soviet folklorist Vera Krupyanskaya (Moscow) during her visit to the Latvian SSR. 1949. MNM 5893. 


\section{Bērzkalne's Background}

Bērzkalne belonged to the first generation of professional Latvian folklorists who received their education in folkloristics, and not in other fields of the humanities. Her higher education was in Kazan, Russia, where she attended the Higher Women's Courses (1913-1917). The degree obtained was Candidate of Philology. In Kazan, her lecturer in comparative linguistics and folkloristics was Walter Anderson. Starting from 1922, Bērzkalne continued her linguistic and folkloristic studies at the University of Tartu. There again she studied under the guidance of Professor Anderson. In 1935 she successfully completed her doctoral studies and in 1942 defended her dissertation "The Song of the Youth Who Died in Sorrow: Its Primary Form and Latvian Versions" (LVA Bērzkalne 1941), receiving her doctoral degree in Estonian and Comparative Folkloristics. Under the Nazi German occupation she purposefully chose to change her dissertation language from German to English, thus demonstrating non-violent resistance towards the Nazi regime. The same year she published a shortened translation of her study in Latvian (Bērzkalne 1942).

In the biographical documents of Bērzkalne, a threefold professional identity is demonstrated. First, she identified with the role of folklore researcher. Second, in 1924 she established and led the Archives of Latvian Folklore (until 1929). The Archives was the first of its kind in the Baltic countries. It served both as a national folklore repository and a support institution for folklore researchers in Latvia and abroad. Third, in addition to folkloristics, Bērzkalne was a Latvian language teacher in Riga; her workplace was Riga Secondary School No. 2. This pedagogical work offered Bērzkalne's financial stability, though it was not much loved by her. This occupation provided subsistence guarantees for her throughout the unstable financing of the Archives.

Living in Latvia, Bērzkalne was an international player of interwar folkloristics. She communicated and cooperated on a daily basis with folklorists from other countries. Among her foreign colleagues were Anderson, Loorits (Estonia), Kaarle Krohn, Elsa Enäjärvi-Haavio (Finland), John Meier (Germany), and many more.

For Bērzkalne, the methodological foundation in folklore research was the historical-geographical method, or the Finnish School, which she learned from one its pioneers, Professor Anderson. Bērzkalne felt an inner responsibility to introduce the method to Latvian scholarship. She consistently promoted the historical-geographical method and the folkloristic work of her Estonian and Finnish peers in her publications and public presentations.

\section{Attacks and Accusations}

In the 1920s, there were several folklorists in Latvia who found the standards of Finnish folkloristics very useful in their studies and publications of folklore texts. However, Bērzkalne was the only fully dedicated representative of the Finnish folklore research method. Her attachment to Finnish standards and application of the historical-geographical method in her research led, during the late 1940s and early 1950s, to the flag bearer of Soviet folkloristics in the Latvian SSR, Niedre, criticising her sharply in several publications. Being responsible for the development of the new field of Soviet folklore 
studies, Niedre focused particularly on an assessment of docent Bērzkalne's scholarly and political views.

From 1945 to 1950, Bērzkalne was a lecturer in folklore at the Faculty of Philology of the Latvian State University and at the same time was a research assistant at the Institute of Folklore, at the Department of Latvian and Russian Folklore. Her closest colleagues were the chief of the department, writer and medic by background, Andrejs Kurcijs (1884-1959) as well as folklorists Birkerts, Boriss Infantjevs (1921-2009), and Jansons.

During the second half of the 1940s, the lack of professionals in folklore studies was an important factor in employing scholars from the interwar period. Bērzkalne took care to increase her 'political and scientific qualifications', as did everyone at that time. However, it was not taken too seriously; for Bērzkalne, it was a kind of bureaucratic task. Her attitude was a mixture between a desire to stay in her profession and an irony towards everything Soviet. As remembered by her younger colleague, Infantjevs, she considered the ideological demands a foolish farce (LFK [2175]: Infantjevs 2007).

In the first years after the Second World War, the historical-geographical method was still an organic part of basic folklore studies. It was taught not only by Bērzkalne in her lectures, but also by her younger and gifted colleague Arturs Ozols as a part of the introductory course in folklore.

The turning point for Latvian folklorists whose formative professional years had been before the Soviet invasion was a publication by a comrade identified as "Rešals" (1947: 3) in the Lieratūra un Māksla ('Literature and Art') newspaper. The author of the commentary was anonymous; in other words, authorship was hidden behind the pseudonym Rešals, which is probably derived from the Russian word meaning 'decision'. It is possible that the writer was a colleague of the person it accused.

Rešals' publication contribution was written as encouragement to the Faculty of Philology to evaluate more profoundly the ideological loyalty of its personnel. The author of the publication referred critically to the research approach used by Jansons as demonstrated at his lectures (as he was a representative of the so-called Kultur-Kreise ('cultural circle') theory of cultural ethnology, he might well have advocated the principles of that approach). As the theoretical impurity of the Folklore Department came under the magnifying glass, Bērzkalne and the Finnish School was next on the list for ideological scrutiny. So, the offensive against her and the rudimentary bourgeois method, the Finnish School, began.

Soon Niedre denounced his former scholarship and in particular the Finnish School represented by Bērzkalne. He also actively raised objections against Bērzkalne and her theory in the minutes both of the institute and Faculty of Philology. In 1947, Niedre published an article in the journal Karogs ('Flag') with the title "Reactionary Theories in Latvian Folkloristics" in which he outlined some undesirable theories from the past: the migratory theory (i.e. the historical-geographical method) being first, followed by the magic-mythological and folklore extinction theories. The useless nature of the historical-geographical theory was explained through criticism of Bērzkalne's views. However, the author of the article based his opinion not on her scientific publications but on the contents of her University lectures (Department colleagues quite often assisted each other at the academic work, thus they had an insight into the problems discussed and the approach of lecturing). 
Niedre stressed that Soviet scholarship needed to turn against any kind of formalism, and produced a very technical analysis of the historical-geographical method, criticising Bērzkalne for slavishly following the requirements of the method. However, the main argument was against the Finnish School's presumption that culture travelled from the centres to the periphery, from higher cultures to lower cultures, etc. Ironically, Soviet folkloristics did not deny expansion and derivation of forms of folk culture from higher cultures completely. Since Russia was supposed to be the centre of Soviet culture, Russian folklore was supposed to be the starting point for the diffusion of folk culture. Niedre did not even find Bērzkalne's comparative literature studies acceptable because some Western borrowings were mentioned (Alexander Pushkin's borrowings from Johann Wolfgang Goethe's motifs, etc.).

A year later, in May of 1948, skipping other schools and theories Niedre turned directly to Bērzkalne and the Finnish School in his article "Lecturer Anna Bērzkalne's Case". The focus of the publication was Bērzkalne's paper, "My Earlier and Current Methods in Folkloristics", which was presented in the same month before the academic staff of University (unfortunately neither any of Bērzkalne's notes nor the manuscript of her presentation were archived). In this self-critical presentation Bērzkalne was supposed to say farewell to the historical-geographical method for good and demonstrate an acquaintance with the "method of Marxist dialectics".

Instead of the expected ideological confession, Bērzkalne, according to Niedre's statement, gave the audience an unpleasant surprise, not only by repeating her previously held theoretical principles, but, moreover, by denying the general Soviet presumptions of class differences. She had said jokingly that in the countryside where she grew up there were no visible differences between the servants and the hosts. In the second of his anti-Bērzkalne publications, Niedre revealed the purpose and the didactic meaning of his criticism: no one coming from the idealistic spheres of scholarship should keep his or her academic positions by verbal witness of Marxism only. Marxism should be applied in reality, to wit, in scientific studies, not in words only.

In 1951, after a pause of two and a half years, Niedre (1951a) published his most extensive essay, "The Development of Latvian Folkloristics and the Fight against the Remains of the 'Finnish School"', based on his presentation at the First Conference of Baltic Folklorists, held in Riga on March 25-29, 1951 (Niedre 1951b). It was a programmatic article dealing with the disciplinary history of the 1920s and 1930s. This time, Niedre did not blame Bērzkalne alone, but rather he made a systematic examination, and, as a result, connected more names with the Finns (at least by use of Antti Aarne's typology of folk tales). However, in the 1950s, Bērzkalne was the only folklorist to embody the Finnish School within the Latvian SSR, since Šmits had passed away, Straubergs had emigrated to Sweden, and Bērziņš had fled to Germany and later to the US. Moreover, Niedre's last article attacking Bērzkalne was published even after she was removed from any academic position within Soviet folkloristics (she left in 1950). Thus, there was not the slightest chance of her returning to academia.

Niedre used heightened language in his publications discrediting the Finnish School. No one will find anything similar in Latvian folkloristics either before or after Niedre. His stylistic approach was a dense combination of Soviet totalitarian phrases (such as the "paramilitary ideological front" a. o.) and a gradually increasing ideology of mes- 
sage. The shaming tone of the publication was used to obliterate the folklore research methods and the folklorists of the past:

By recognising the folk poetry in the old songs, fairytales, beliefs, cemetery inscriptions and similar oddities and denying folklore itself as a historical category, the bourgeois Latvian folkloristics led by the spirit of P. Schmidt's, K. Strauberg's and A. Bērzkalne's 'Finnish school' completely ignored the creative work of contemporary folk. It excluded from collectors' sight the working class and revolutionary folklore (Niedre 1951a: 1205)

In the initial period of Latvian Soviet folkloristics, the denial of the interwar period theories was an unquestionable methodological claim, just as was the glorification of Stalin throughout the period of his personality cult. However, when criticising theories, other scholars tried not to point at individuals. The only critic to go beyond this unwritten rule was Niedre. He was too enthusiastic about constructing the new Soviet folkloristics.

\section{Efforts to Adapt}

In these very unpromising circumstances, under the Soviet thumb, Bērzkalne tried to introduce her 'bourgeois' scholarly principles, i.e. the historical-geographical method, to Soviet folkloristics indirectly. She carried out four studies between 1947 and 1950 which at least thematically (although not methodologically) tried to be in tune with the ruling regime. Their topics were Russian rhyme (chastushki), as well as Comrade Stalin and Lenin (as they appeared in the songs of Soviet peoples). However, her efforts to adapt to the framework of Soviet folkloristics was not successful - her studies received criticism and were never published.

The studies were: "Similar Motifs in Latvian Unrhymed Quatrains and Russian Rhymes (chastusha)" (1949; see LFK Bērzkalne 1949), "Comrade Stalin in the Songs of the Soviet Peoples" (1949; LUAB R Bērzkalne 1949), "Comrade Stalin as the Leader of Constructing Socialism in the Songs of the Soviet Peoples" (1950; LUAB R Bērzkalne $1950 b)$ and "V. I. Lenin in the Poetry of the Soviet Peoples" (1950; LUAB R Bērzkalne 1950a).

"Similar Motifs in Latvian Unrhymed Quatrains and Russian Rhymes (chastusha)" was meant to promote Bērzkalne's career during the Soviet period. She had planned this article as a requalification work. However, despite her efforts, it was discussed (and finally rejected for publication) only in a narrow circle at the closed meetings of the Folklore Institute. This comparative study sought to find similarities, influences and the beginnings of the folk poetry motifs found both in Russian and Latvian folklore. In several chapters and subchapters, Bērzkalne worked out a pretty detailed though not consistent system of comparison, and her approach, although never mentioned as such, heavily borrowed from the Finnish School. Instead, she richly referred to the authorities of the regime (the leaders of Soviet politics and scholarship) while also attempting an imitation of totalitarian language: 
Tsarist bureaucracy and bourgeois nationalism created fences of mistrust and blame between the Latvian and Russian nations, and breaking them can only bring to human consciousness better knowledge and understanding of others. [...] I would like to hope that knowing Russian rhymes better, which are such peculiar, ingenious, and powerful expressions of the creativity of the working class today, that affectionate feelings towards the great Russian people whose ancient role in the development of Latvian culture has not yet been sufficiently explored, will only grow stronger. (LFK Bērzkalne 1949: 131, 133)

In "Similar Motives in Latvian Unrhymed Quatrains and Russian Rhymes (chastusha)", Bērzkalne tried to balance Soviet folkloristics and her theoretical basis, the Finnish School, whereas the rest of her Soviet period papers, her Soviet folklore studies, is resigned to following the rules. Although she compares a wide range of international sources (Soviet folklore produced by representatives of different Soviet peoples), the text shows neither a liability in the sources being analysed, nor an authentically Soviet style of expression. Additional historical sources prove Bērzkalne's lack of seriousness regarding Soviet folklore studies.

In 1949, this study by Bērzkalne was added to the publishing plans of the Institute of Folklore for 1950. 2,000 copies would be printed by the Latvian State Publishing House. However, the volume printing plans remained unfulfilled, and the manuscript was not published.

Both "Comrade Stalin in the Songs of the Soviet Peoples" and "Comrade Stalin as the Leader of Constructing Socialism in the Songs of the Soviet Peoples" are non-critical compilations of short Soviet folklore texts with some of Bērzkalne's introductory words. The first one was presented at the Faculty of Philology of the Latvian State University. Both texts express their gratitude to Stalin and follow the standardised linguistic style of public texts of the Soviet totalitarian regime. In the introduction to the texts, Bērzkalne refers to the authorities of official ideology, such as Henri Barbusse, Maxim Gorky, Alexey Stakhanov, and Lavrentiy Beria. Both stylistically and in their substance, Bērzkalne's essays fit into the corpus of similar texts created during Stalin's personality cult.

"V. I. Lenin in the Poetry of the Soviet Peoples" was an anniversary lecture prepared for the celebration of Lenin's (posthumous) 80th birthday at the Academy of Sciences in April 1950. The composition of the report is similar to the essays on Stalin: first, extracts of Lenin's writing are given, followed by a series of examples of Soviet folklore. Bērzkalne's conclusions to the lecture were a rather pathetic attempt to play along with the accepted Soviet ideology of the time:

In folk poetry, the image of Lenin, unleashed by all chance and transient, rises up in his immortality as a giant, a flaming star, a signpost, a wake-up call and a liberator, a giver of light and heat, a leader toward a new, bright future for humanity. In this image of folk poetry, V. Lenin's spiritual being appears in its most truthful truth. (LUAB R Bērzkalne1950a)

Bērzkalne's Soviet-era studies provide evidence either of her efforts to recognise the requirements of Soviet ideology and to adapt to them, or an ironic distance with par- 
ody-like creativity for scholarly work. The hidden true motivation of Bērzkalne may be different in each case and can only be guessed at today. However, combining the comparative folklore research approach of the Finnish School with pseudo-scholarly Soviet principles turned out to be a risky game with a negative outcome for the scholar.

The year 1950 was marked by the end of compromise with the 'remnants of the past' within the discipline of Soviet folklore studies. In Bērzkalne's case, as the records of the Institute of Folklore reveal, she had no capacity to compromise indefinitely. In 1950, she openly criticised the protagonist of Soviet folkloristics in Latvia, Niedre, in the minutes of Institute's Scientific Council for having no capacity for self-criticism and being ignorant and short-sighted about the main tasks of folkloristics over the coming five years (March 3, 1950). Bērzkalne called Niedre's critique on her study "Similar Motives in Latvian Unrhymed Quatrains and Russian Rhymes (chastusha)" formalistic and pointed out his overall biased fallacies; meanwhile she expressed hope that folklorists from Moscow, i.e. non-provincial scholars, would demonstrate very different opinions (May 11, 1950). Such a confrontation with the powers that be put an end to her career. Subsequently, she ultimately lost her position at the Institute of Ethnography and Folklore when it was restructured in 1950. In 1951, when a professional career in Riga was no longer possible, Bērzkalne cherished the idea of passing a folklore exam in Moscow and thus gaining the recognition of Moscow's folklore specialists. However, these plans did not materialise and to date there is no archival evidence of where they got stuck. After her retirement, Bērzkalne spent the last years of her life with impaired health with her brother's family supporting her through these hard times.

\section{CONCLUSION}

After the Second World War, the folklore research approaches related to 'bourgeois folkloristics' were harshly criticised and banned by Soviet folklorists. The most expressive critique was Niedre's, and the method criticised most was the historical-geographical method, the patroness and practitioner of which in the interwar period was Bērzkalne. Despite the denial, in some studies of this period the principles of the Finnish School were used in a veiled manner without exact reference to it (Infantjevs 1950: 176).

On one hand, there was the political disruption of the Soviet period, which argued against the methods that Latvian folklorists applied in the 1920s and 1930s. On the other hand, some of these methods would probably have retreated and lost significance in Latvian folkloristics 'naturally', without any ideological pressure. The sad and unchangeable aspect of the history of folkloristics in the Soviet Stalinist period is awareness of the fact that the unique voices of folklorists living in the unfortunate early Soviet era have been silenced.

During the Soviet era, the names of the Latvian folklorists who belonged to the interwar period's intellectual community were forgotten. They have only been rehabilitated during the Third Latvian National Awakening (the early 1990s) and it took until the 21st century for their contributions to be thoroughly studied. 


\section{NOTES}

1 Roberts Pelše (1880-1955) was a literary scholar, dean of the Faculty of Philology at the Latvian State University (1945-1949) and director of the Institute of Folklore of the Academy of Sciences of the Latvian SSR (1946-1955).

2 The Archives of Latvian Folklore regained its historical name in 1992.

\section{SOURCES}

LFK = Archives of Latvian Folklore (Latviešu folkloras krātuve), Institute of Literature, Folklore and Arts of the University of Latvia:

LFK Bērzkalne, Anna. 1949. Lìdzīgi motīoi latviešu bezatskaņu četrrindās un krievu atskaņpantos (̌̌astuški).

LFK [2175]: Infantjevs 2007. Rita Treija's collection, interview with Boriss Infantjevs (19212009). 8/06/2007.

LFK f19510012 - a photo, 1951.

LFK f19510023 - a photo, 1951.

LUAB R = Department of Rare Books and Manuscripts of the Academic Library of the University of Latvia:

LUAB R Bērzkalne, Anna. 1949. Biedrs Staḷins padomju tautu dziesmās. LUAB R A. Bērzkalnes f. 3., 12 .

LUAB R Bērzkalne, Anna. 1950a. V. I. L̦enina tēls padomjtautu dzejā. LUAB R A. Bērzkalnes f. 3., 13.

LUAB R Bērzkalne, Anna. 1950b. Biedrs Staḷins padomjtautu dziesmās kā sociālistiskās celsmes vadìtājs. LUAB R A. Bērzkalnes f. 3., 14.

LVA = State Archive of Latvia:

LVA Bērzkalne, Anna. 1941. The Song of the Youth Who Died in Sorrow: Its Primary Form and Latvian Versions. LVA, 1756. f., 2. apr., 1. 1.

MNM = Madona Museum of Local History and Art:

MNM 5893 - a photo, 1949.

\section{REFERENCES}

Aarne, Antti. 1910. Verzeichnis der Märchentypen. FF Communications 3. Helsinki: Suomalaisen Tiedeakatemian toimituksia.

Bērzkalne, Anna. 1942. Dziesma par žêlumā nomirušo puisi. Rīga: Latvju Grāmata.

Bleiere, Daina. 2006. Represijas pret Latvijas iedzīvotājiem 1944.-1965. gadā. - Latvijas Vēstures Institūta Žurnāls 1: 110-135.

Bula, Dace, ed. 2014. Latviešu folkloristika starpkaru periodā. Rīga: Zinātne.

Bula, Dace, ed. 2017. Latvian Folkloristics in the Interwar Period. Folklore Fellows' Communications 313. Helsinki: Academia Scientiarum Fennica.

Bunkše, Edmunds V. 1979. Latvian Folkloristics. - The Journal of American Folklore 92 (364): 196214. DOI: https://doi.org/10.2307/539388.

Ekmanis, Rolfs. 1959. Padomju mitologiija Latvijā. - Jaunā Gaita 21: 116-118.

Gale Carpenter, Inta. 1988. Being Latvian in Exile: Folklore as Ideology. A PhD Dissertation. Indiana University. 
Gale Carpenter, Inta. 2017. Folklore as a Source for Creating Exile Identity among Latvian Displaced Persons in Post-World War II Germany. - Journal of Baltic Studies 48: 205-233. DOI: https://doi.org/10.1080/01629778.2016.1196379.

Goršič, Ave. 2018. The Position of Folk Belief in Estonian Folkloristics during the Soviet Era. - Visions and Traditions: Knowledge Production and Tradition Archives. Folklore Fellows' Communications 315, edited by Lauri Harvilahti, Audun Kjus, Clíona O'Carroll, Susanne ÖsterlundPötzsch, Fredrik Skott and Rita Treija. Helsinki: Academia Scientiarum Fennica, 122-140.

Infantjevs, Boriss. 1950. Padomju Latvijas folkloristu sasniegumi 10 gados. - Latvijas PSR Zinātņu Akadēmijas Vēstis 7: 176-178.

Kaeser, Marc-Antoine. 2008. Biography as Microhistory: The Relevance of Private Archives for Writing the History of Achaeology. - Archives. Ancestors. Practices: Archaeology in the Light of its History, edited by Nathan Schlanger and Jarl Nordbladh. New York, NY; Oxford: Berghahn Books, 9-20.

Kalniņa, Ieva. 2007. Latviešu padomju folkloras konstrukcija. - Kultūra un vara: Raksti par valodu, literatūru, tradicionālo kultūru, compiled by Janīna Kursīte and Jolanta Stauga. Rīga: LU Akadēmiskais apgāds, 30-40.

Kencis, Toms. 2017. The Soviet Project of New Folklore. - Mapping the History of Folklore Studies: Centers, Borderlands and Shared Spaces, edited by Dace Bula and Sandis Laime. Newcastle upon Tyne: Cambridge Scholar Publishing, 154-169.

Ķencis, Toms. 2019. Vācot padomju folkloru. Rīga: LU Literatūras, folkloras un mākslas institūts.

Keruss, Jānis. 2011. Sovjetizācija (1944-1956). - Latvijas Universitātes Vēstures un filozofijas fakultātes vēsture padomju laikā: personības, struktūras, idejas (1944-1991), edited by Jānis Keruss, Ineta Lipša, Inese Runce and Kaspars Zellis. 2nd edn. Rīga: LU Akadēmiskais apgāds, 87-129.

Klein, Barbro. 2017. Baltic Folklorists and Ethnologists in Sweden: Reflections and Scholarship in Exile and Discipline Formation. - Mapping the History of Folklore Studies: Centers, Borderlands and Shared Spaces, edited by Dace Bula and Sandis Laime. Newcastle upon Tyne: Cambridge Scholar Publishing, 85-110.

Klotiņ̌̌, Arnolds. 2018. Mūzika pēckara staḷinismā: Latvijas mūzikas dzīve un jaunrade 1944-1953. Rīga: LU Literatūras, folkloras un mākslas institūts.

Korb, Anu. 2017. On Instructing Collectors of Estonian Folklore under the Soviet Regime. - Mapping the History of Folklore Studies: Centers, Borderlands and Shared Spaces, edited by Dace Bula and Sandis Laime. Newcastle upon Tyne: Cambridge Scholar Publishing, 111-131.

Kulasalu, Kaisa. 2017. Sovietisation of Folkloristics in Late Stalinist Estonia. - Mapping the History of Folklore Studies: Centers, Borderlands and Shared Spaces, edited by Dace Bula and Sandis Laime. Newcastle upon Tyne: Cambridge Scholar Publishing, 132-153.

Miller, Frank J. 1980. The Image of Stalin in Soviet Russian Folklore. - The Russian Review 1: 50-67. DOI: https://doi.org/10.2307/128551.

Niedre, Jānis. 1947. Reakcionārās teorijas latviešu folkloristikā. - Karogs 5: 462-467.

Niedre, Jānis. 1948. Docentes Annas Bērzkalnes "lieta”. - Literatūra un Māksla, May 16: 6.

Niedre, Jānis. 1951a. Latviešu folkloristikas attīstība un cīṇa ar "somu skolas" paliekām. - Latvijas PSR Zinātņu Akadēmijas Vēstis 8: 1199-1210.

Niedre, Jānis. 1951b. Baltijas padomju folkloristu konferencei sanākot. - Literatūra un Māksla March 25: 1.

Panchenko, Alexander. 2005. The Cult of Lenin and "Soviet Folklore". - Folklorica X (1): 18-38.

Rešals, M. 1947. Profesora J. A. Jansona "personīgie" uzskati. - Literatūra un Māksla, May 16: 3.

Saarlo, Liina. 2018. Changing Practices of Folk Song Collection Manifested in the Estonian Kodavere Regilaul Corpus. - Visions and Traditions: Knowledge Production and Tradition Archives. Folklore Fellows' Communications 315, edited by Lauri Harvilahti, Audun Kjus, Clíona O'Carroll, Susanne Österlund-Pötzsch, Fredrik Skott and Rita Treija. Helsinki: Academia Scientiarum Fennica, 81-100. 
Sokolov, Yuriy Matveyevich. 1938. Russkiy fol'klor: Uchebnik dlya vysshikh uchebnykh zavedeniy. Moskva: Uchpedgiz. [Соколов, Юрий Матвеевич. 1938. Русский фольклор: Учебник для высиих учебных заведений. Москва: Учпедгиз.]

Sorokina, Marina Yu. 2011. Within Two Tyrannies: The Soviet Academic Refugees of the Second World War. - Proceedings of the British Academy 169: 225-238. DOI: https://doi.org/10.5871/ bacad/9780197264812.003.0015.

Stamati, Iurie. 2015. Two Chapters in the Sovietization of Romanian Archaeology (From the Late 1940s to the Mid-1950s). - Arcaeologia Bulgarica XIX (1): 81-95.

Stradiņš Jānis. 2004. Totalitāro okupācijas režìmu represijas pret Latvijas zinātni un akadēmiskajām aprindām (1940-1945). - Latvijas Vēsturnieku komisijas raksti 13. Rīga: Latvijas vēstures institūta apgāds, 130-164.

Šneidere, Irēne. 2003. Sabiedriskā doma Latvijā: ieskats pirmajos pēckara gados. - Latvijas Vēstures Institūta Žurnāls 2: 99-115.

Treija, Rita. 2017. Anna Bērzkalne (1891-1956). - Latvian Folkloristics in the Interwar Period. Folklore Fellows' Communications 313, edited by Dace Bula. Helsinki: Academia Scientiarum Fennica, 168-176.

Treija, Rita. 2018. Anna Bērzkalne. Rīga: Zinātne.

Vidutis, Ričardas. 1987. Jonas Balys. Lietuviu žemdirbystès papročiai ir tikéjimai. Silver Spring, MD: Lithuanian Folklore Publishers. 